\title{
An Economic Analysis of Chip Utilization in Alberta
}

\author{
by
}

\author{
Alex P. MacDonald ${ }^{1}$ and Michael Carroll ${ }^{2}$
}

\begin{abstract}
This study summarizes two research projects from 1980 and 1983. Geldhart's study (1980) was established with the need to document the pricing policies of the chip buyers to determine whether monopsonistic price discrimination existed. MacDonald's study (1983) looked at how the pricing policies affected the chip suppliers' rates of return and considered what price increases were needed to effectively allow chipping operations to be profitable. The conclusion of this analysis is that rather than regulate chip marketing policies of pulp-mills, it is more effective to ensure that alternative roundwood supplies are priced up to their residual value. Further evaluation of the benefits and costs involved in the location of new pulpmills under a scenario of increasing residue utilization would be needed to determine the impact on the development of a healthy pulp industry. A policy that promotes only residue utilization would conflict with the priority of promoting larger industry development.
\end{abstract}

\section{Résumé}

Cette étude résume deux projets de recherche de 1980 et de 1983. L'étude de Geldhart (1980) a été menée en soulignant le besoin de référer aux politiques de prix des acheteurs de copeaux, afin de déterminer s'il existe une discrimination de prix en terme de monospone. L'étude de MacDonald (1983) étudia comment les politiques de prix affectent le reour sur l'investissement des fournisseurs de copeaux et quelles sont les augmentations de prix nécessaires pour rendre effectivement rentables les opérations de déchiquetage. La conclusion de cette analyse révèle qu'au lieu de régulariser les politiques de prix des copeaux des usines de pâte, il est plus efficace de s'assurer que les autres sources d'approvisionnement de bois ronds sont évaluées selon leur valeur résiduelle. Une étude plus poussée des coûts et des bénéfices engendrées lors de la planification de nouvelles usines, selon un scénario d'utilisation accrue des résidus, serait nécessaire afin de déterminer l'impact du développement d'une industrie papetière en bonne santé. Une politique basée sur seulement l'utilisation des résidus aboutirait à un conflit de priorité avec la promotion du développement de grandes entreprises.

\section{Introduction}

The utilization of wood residues from sawmills is of increasing importance in the long run as fibre costs rise. The market for wood chips is often imperfectly competitive and this has created a controversy over prices and quantity of chips supplied to pulpmills. It is an interesting facet of marketing to consider the monopsonistic chip market, in which a single pulpmill purchases chips within its reasonable chip haul distance for numerous sawmills.

Whether the firm is a perfect competitor or a monopsonist in a factor market, the equilibrium condition is the same. Equilibrium factor employment occurs when the Marginal Revenue Product (MRP) of chips equals the Marginal Cost (MC) of chips at the pulpmill. When the firm is a perfect competitor in the factor market the MC of chips at the pulpmill equals the price of chips.

\footnotetext{
Alex P. MacDonald graduated from the Department of Rural Economy University of Alberta, in spring 1983, with an M.Sc. in Forest Economics. ${ }^{2} \mathrm{Dr}$. Carroll was an Associate Professor for the Department of Rural Economy. University of Alberta. He is a consultant now working in Esher Surrey, England.
}

\section{Marginal Productivity Analysis}

In a fully competitive market at equilibrium, the marginal revenue product (MRP) ${ }^{3}$ should equal the marginal cost $(M C)^{4}$ of chips at the pulpmill, and both should equal the price of chips. However, if a pulpmill is a monopsonist ${ }^{5}$ the $\mathrm{MC}$ of chips to the pulpmill is greater than the price of the chips. This difference between a fully competitive equilibrium and a monopsonist arises because in order to obtain additional chips the monopsonist must increase the price for all chips that are purchased.

Figure 1 shows a set of generalized prices and quantities. Assume the total pulp industry is the same scale under all three forms of market structure, and the marginal revenue curve for the pulp industry (MR pulpmill) is the demand curve for chips as input. In a perfectly competitive market the marginal cost of chips delivered to the pulpmills is the sum of

\footnotetext{
$3 \mathrm{MRP}$ is the revenue from an extra unit of output.

${ }^{4} \mathrm{MC}$ is the cost of producing an extra unit of output.

${ }^{5} \mathrm{~A}$ monopsonist is the only purchaser in a market.
} 


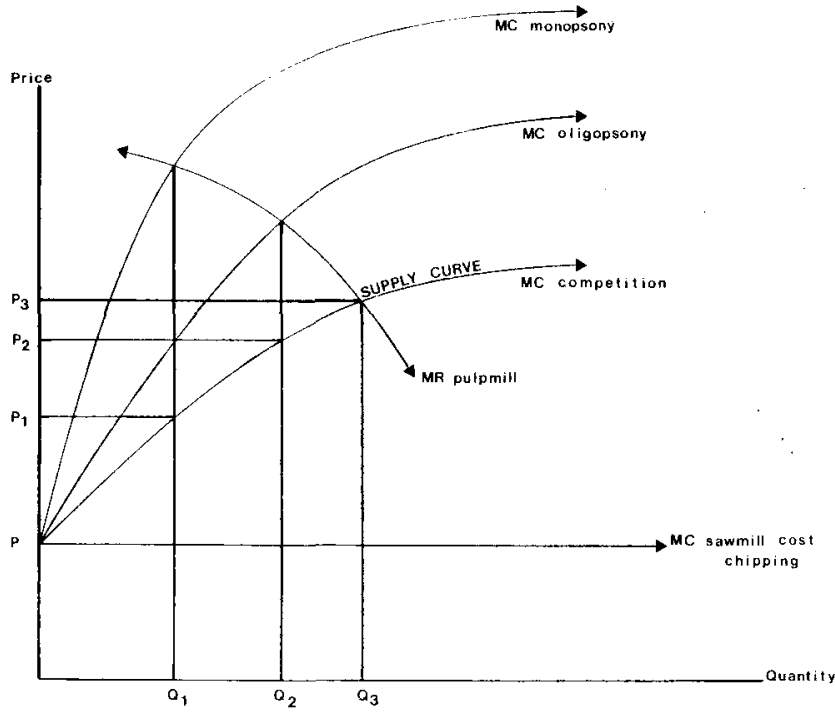

Figure 1. A graphical representation of monopsony, oligopsony, and perfect competition

the transportation costs and the chipping production costs at the sawmill. The supply curve for the industry is given by (MC competition) line in Figure 1, and is the sum of individual sawmill production and transportation costs. At the point of intersection of the $M R$ and $M C$ curves $Q_{3}$ chips would be bought at price $P_{3}$. Under a perfectly competitive system the most chips would be bought at the highest price.

The monopsonist will maximize profits by buying quantity $Q_{1}$ chips at price $P_{1} \cdot Q_{1}$ corresponds to the intersection of the monopsonists marginal cost and marginal revenue curve. $P_{1}$ is the price which the monopsonist must offer to obtain $Q_{1}$. Buying more than $Q_{1}$ would take the firm beyond the point of intersection to the marginal revenue and monopsonist's cost curve (MC monopsony) and consequently reduce net revenue to the monopsonist.

In an oligopsonistic market the marginal cost curve of the pulpmills will be less steep as indicated by the (MC oligopsony) curve. The intersection of the (MC oligopsony) and (MR pulpmill) curves show that price $P_{2}$ and quantity $Q_{2}$ would be bought in an oligopsonistic market.

\section{A Comparison of Nondiscriminatory and Discriminatory Pricing}

It is assumed that all sawmills producing chips have the same marginal costs of chip production regardless of location. In Figure 2, point $D$ is the location of the pulpmill. The available quantity of chips increases by taking ever more distant sawmills into the chip marketing area. The optimal price and quantity for the monopsonist would be $Q_{1}$ chips at the price $P_{1}$.

The effect of transportation costs on the production of chips is shown in Figure 2, indicated by the transporation costs increasing but at a decreasing rate. This creates the form of the supply curve. The amount supplied will depend upon the number of sawmills that can cover their production and transportation costs at the price offered for chips.

If the pulpmill buys at price $P_{1}$, a sawmill with no variable transportation costs, i.e., at point D, would capture its

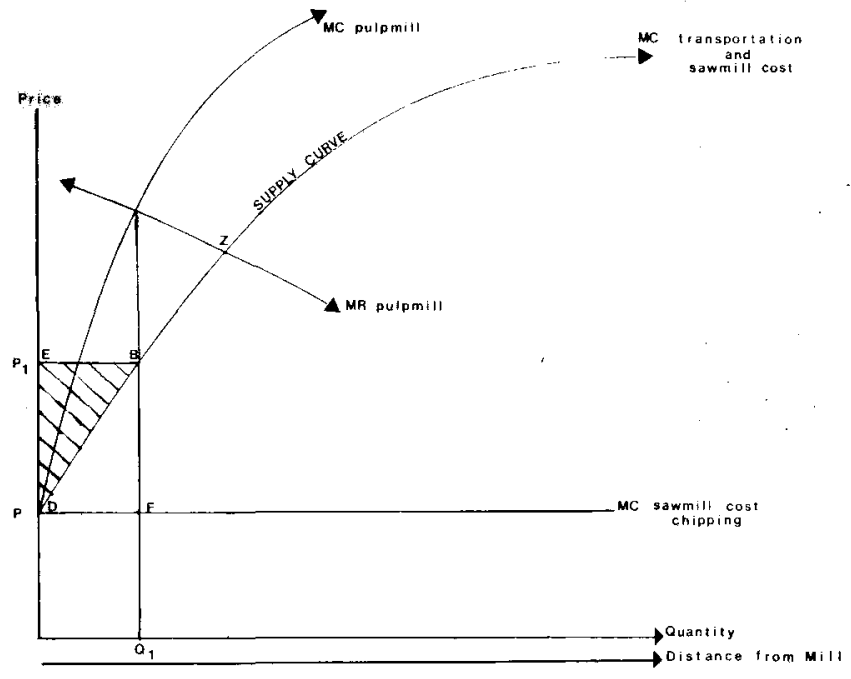

Figure 2. Nondiscriminatory and discriminatory pricing

producer's surplus ${ }^{6}$, derived from $P_{1}-P$ times the quantity of chips produced by the sawmill. All sawmills between $D$ and $F$ have some producer's surplus, the total of which is indicated by DEB (shaded area). A sawmill at point $F$ has no producer's surplus since $\left(P_{1}-P\right)-($ transportation cost $)=$ zero. Beyond Point $F$ the monopsonistic pulpmill will buy no more chips because the MC of acquiring the chips will be greater than the resulting MR

However, with a discriminatory pricing policy, the monopsonist discriminates between sawmills by offering a price $P$ at the sawmill, so that it just covers the sawmill's marginal cost of chipping, rather than a delivered price $P_{1}$, which provides a producer's surplus to the nearby mills. The pulpmill pays for the transportation costs in addition to the chipping cost to create an effective delivered price which follows line DB and hence the supply curve. By paying the price $P$ to all sawmills, and adding the actual transportation costs, rather than paying a price $P_{1}$ to all sawmills, the producer's surplus DEB is eliminated as payment to the sawmills and is retained by the pulpmill. Thus the pulpmill captures the economic rent available from the resource. The pulpmill through this discriminating policy will act as though it were a perfectly competitive industry in the sense that its MC curve becomes the same as the supply curve for the industry. The discriminating pulpmill will buy chips from sources beyond the nondiscriminating breakeven point $F$, and extend its chipshed to $Z$. A discriminatory price policy allows the monopsonist to take full advantage of his ability to pay a minimum price, equal to the marginal costs of chipping by the sawmill.

A discriminatory price exercised by a monopsonist has the effect of eliminating the extra cost to the monopsonist of having to increase prices to all sawmills in order to obtain extra chips. The discriminatory monopsonist thus has a marginal cost curve equal to only the transporation and sawmill chipping costs. The quantity of chips demanded would be expected to be the same as in a perfectly competitive market of the same size but the price paid to sawmills will only be equal to each individual sawmill's marginal cost and the pulpmill will take the responsibility for transportation costs.

EProducer's surplus encompasses economic rent and entrepreneurial profit but not the cost of capital. Economic rent is the surplus of income to bring a factor into production. This concept of rent may be broadened to include any input which earns a surplus. 


\section{Research Documenting The Discriminatory Pricing Policy}

In the absence of discriminatory pricing the nearby sawmills will get a higher price than the distant sawmilis. Conversely with discriminatory pricing nearby mills no longer receive a higher price, but alf mills receive the same price regardless of location. Therefore, evidence of uniformity of prices paid at the sawmill may indicate discriminatory pricing. Under discriminatory pricing there will be little or no effect of location and transport costs on the profitability of chipping operations. A discriminatory monopsonist will always have higher profits than a nondiscriminatory monopsonist, and so it can be assumed monopsonists will always attempt to discriminate between sawmills and offer the minimum uniform price to each sawmill.

A study by Geldhart and Carroll (1980) showed that chip prices in Alberta did not reflect the transport costs to the pulpmill and in the case of one pulpmill price discrimination was occurring due to evidence of some uniformity in pricing. Six sawmills in Group A, from Table 1, provided 170,000 Bone Dry Units (BDU $=2400 \mathrm{lbs}$. of chips) in 1976 to one of the Alberta pulpmills. Two of the sawmilis closest to the pulpmill received $\$ 25 /$ BDU. The other sawmills 125 miles to 250 miles from the pulpmill received $\$ 20 / \mathrm{BDU}$. Transport cost varied from $\$ 1.99$ to $\$ 15.29 / \mathrm{BDU}$

The chip price plus transport costs to the pulpmill gives the effective delivered price. Chips from nearby mills had an effective delivered price of $\$ 27$. The effective delivered price was $\$ 35.30$ for a sawmill 250 miles away.

There is little or no effect of location. Firms (1) and (2) do receive a higher price, but with transport costs only being $7.3 \%$ of the total price at the pulpmill the sawmill should have received a much higher price. Assuming $\$ 38.00$ per BDU is the cost of chips from pulpmill sources, the two firms should have received $\$ 36.00 / \mathrm{BDU}$ (Column G, Table 1). Transport costs varied $\$ 2$ to $\$ 15.00 / \mathrm{BDU}$, but prices at the sawmill varied only $\$ 5$; therefore, differences in transport costs were not fully reflected in the price at the sawmill.

In the case of another pulpmill (Group B, Table 1), four chip suppliers together provided 45,000 BDU's of chips. Although prices which ranged from $\$ 16.75$ to $\$ 24.00 / \mathrm{BDU}$ were not uniform, the prices at the sawmill did not reflect the differences in transport costs of $\$ 4$ to $\$ 19.51 / \mathrm{BDU}$. The resulting effective delivered prices ranged from $\$ 28$ to $\$ 39 /$ BDU for suppliers varying from 64 miles to 190 miles distance respectively. Neither of these pulpmills were entirely monopsonistic, although only part of their chip markets overlapped with those of other pulpmills.

The conclusion from the survey was that where a relatively uniform price paid at the sawmill was observed, the situation of low transportation for nearby sawmills did not result in correspondingly high chip prices and price discrimination by location took place. Overall the survey showed that at least part of the producer's surplus available to the sawmills was retained by the pulpmill through the use of their monopsonistic market power

\section{Research Documenting the Rates of Return from Chipping}

A study by MacDonald (1983) looked at chip prices in Alberta in considerable detail. The rate of return from chipping operations by sawmills was entirely related to cost factors other than transporation costs. Location should of course, in the absence of discriminatory pricing, be one of the most important factors affecting chipping operation returns.

MacDonald (1983) carried out a survey in 1981 of the thirteen chip producers in Alberta. Chip production, chipping equipment, costs and prices were collected and supplemented by reference to equipment manufacturers and chip producers. The object was to define and calculate the profitability of chipping operations for each sawmill.

Profitability was calculated in terms of an internal rate of return, based on returns to capital over a five-year project life at their current prices. The results are shown in Table 2. It can be observed that five of the 13 firms had an internal rate of return (irr) in their chipping operation of less than $5 \%$. This would normally be considered unacceptably low. The fact that firms might be operating unprofitable chipping operations need not be surprising. The costing procedure used in this study separated the cost of chipping equipment and annua costs to chipping from the rest of the sawmill operation Chipping costs in the cast of the smaller operators were often included in the overall operation of the sawmill, and as such these firms could not recognize their actual return from chipping

The trend of profitability could not be accurately established because of the small sample size and considerable variability. However, with low marginal costs and high efficiency, larger size sawmills tended to have the higher internal rates of return, rather than those located closer to the

\section{Table 1. Sample of wood chip purchases: cost of transportation and price at the sawmill}

\begin{tabular}{|c|c|c|c|c|c|c|c|}
\hline \multirow[b]{2}{*}{ Supplier } & \multirow[b]{2}{*}{$\begin{array}{c}\text { A } \\
\text { Transport } \\
\text { cost } \\
\text { per BDU }\end{array}$} & \multirow[b]{2}{*}{$\begin{array}{c}\text { B } \\
\text { Return } \\
\text { distance } \\
\text { miles }\end{array}$} & \multicolumn{2}{|c|}{ Group A - Pulpmill 1} & \multirow[b]{2}{*}{$\begin{array}{c}E \\
\text { Cost of } \\
\text { chips } \\
\text { pulpmill } \\
\text { sources }\end{array}$} & \multirow[b]{2}{*}{$\begin{array}{c}\text { F } \\
\text { Producer's } \\
\text { surplus } \\
\text { E - D }\end{array}$} & \multirow[b]{2}{*}{$\begin{array}{c}\text { G } \\
\text { Corrected } \\
\text { price } \\
\text { sawmill } \\
\mathbf{C}+\mathbf{F}\end{array}$} \\
\hline & & & $\begin{array}{c}\text { C } \\
\text { Price } \\
\text { at } \\
\text { sawmill }\end{array}$ & $\begin{array}{c}\text { D } \\
\text { Price } \\
\text { at } \\
\text { pulpmill }\end{array}$ & & & \\
\hline 1 & 1.99 & 20 & 25 & 26.99 & 38 & 11.01 & 36.01 \\
\hline 2 & 1.99 & 20 & 25 & 26.99 & 38 & 11.01 & 36.01 \\
\hline 3 & 7.88 & 250 & 20 & 27.88 & 38 & 10.12 & 30.12 \\
\hline 4 & 9.73 & 320 & 20 & 29.73 & 38 & 8.27 & 28.27 \\
\hline 5 & 13.30 & 456 & 20 & 33.30 & 38 & 4.70 & 24.70 \\
\hline 6 & 15.29 & 496 & 20 & 35.29 & 38 & 2.71 & 22.71 \\
\hline \multicolumn{8}{|c|}{ Group B - Pulpmill 2} \\
\hline 1 & 4.04 & 128 & 24 & 28.04 & 38 & 9.96 & 33.96 \\
\hline 2 & 18.46 & 251 & 16.75 & 35.21 & 38 & 2.79 & 18.54 \\
\hline 3 & 19.51 & 282 & 20 & 39.51 & 38 & -1.51 & $\uparrow 8.49$ \\
\hline
\end{tabular}


Table 2. Irr and the effect of changes due to price increases

\begin{tabular}{|c|c|c|c|c|}
\hline \multirow{2}{*}{$\begin{array}{l}\text { Firm } \\
\text { No. }\end{array}$} & \multirow{2}{*}{$\begin{array}{c}\text { Present } \\
\text { irr }\end{array}$} & \multicolumn{3}{|c|}{ Price $\%$ increase or decrease to yield an irr of: } \\
\hline & & $0 \%$ & $5 \%$ & $10 \%$ \\
\hline $\begin{array}{l}1 \\
2 \\
3 \\
4 \\
5 \\
6 \\
7 \\
8 \\
9 \\
10 \\
11 \\
12 \\
13 \\
\end{array}$ & $\begin{array}{r}+1 \% \\
+17 \% \\
+26 \% \\
+17 \% \\
\text { negative } \\
+32 \% \\
+9 \% \\
\text { negative } \\
+36 \% \\
+1 \% \\
+22 \% \\
+34 \% \\
+1 \%\end{array}$ & $\begin{array}{l}+27 \% \\
-21 \% \\
-32 \% \\
-18 \% \\
+66 \% \\
-44 \% \\
-7 \% \\
+38 \% \\
-49 \% \\
+22 \% \\
-18 \% \\
-49 \% \\
+21 \%\end{array}$ & $\begin{array}{l}+43 \% \\
-4 \% \\
-24 \% \\
-7 \% \\
+90 \% \\
-35 \% \\
+3 \% \\
+56 \% \\
-41 \% \\
-38 \% \\
-8 \% \\
-42 \% \\
+38 \%\end{array}$ & $\begin{array}{l}+59 \% \\
+23 \% \\
-14 \% \\
+\quad 6 \% \\
+114 \% \\
-26 \% \\
+20 \% \\
+76 \% \\
-33 \% \\
+54 \% \\
+\quad 4 \% \\
-34 \% \\
+57 \%\end{array}$ \\
\hline
\end{tabular}

pulpmills. The fact that transportation costs and price were not found to have a similar logical relationship with rates of return, obviously provides no possibility for inferring that location was as important as efficiency, which was the a priori expectation for the nondiscriminatory pricing model.

Table 2 indicates a sensitivity analysis with percentage price changes required to achieve $0 \%, 5 \%$ and $10 \%$ rates of return. Four of the mills required at least a $50 \%$ increase in price of chips to achieve a $10 \%$ internal rate of return on their chipping operations as costed out in this study. While it cannot be considered from this that chip prices "should" be higher, it is at least consistent with the notion that some sawmills selling chips in a monopsonistic market in Alberta are not effectively optimising the use of their capital resources given the prices they are offered by the chip purchaser.

\section{Policy Issues for Chip Utilization}

Two policy issues emerge. First, for a given industrial structure a discriminatory pricing policy by the monopsonist ensures that the marginal cost to the pulpmill of chip procurement follows the supply schedule and hence an optimal level of residue will be used. An attempt by government to impose a non-discriminatory pricing policy on pulpmills would enable some sawmills to benefit from their producer's surplus, which would otherwise be captured by the pulpmill. However, if the pulpmill must pay for the sawmill's producer surplus, the pulpmill would desire a lower level of chip purchases, and continued government involvement enforcing transactions would be required to maintain the socially optimum level of wood residue utilization. Administration and enforcement costs would present a continual drain on social net benefits and the only advantage gained is a redistribution of producer's surplus retained by the pulpmills, back to the sawmills.

Thus, chip pricing policy turns out to be only a narrow issue of equity for sawmills. Government influence of resource allocation to pulp production would be easier to maintain and more effective, if pulpmill behavior were controlled through timber leases. For example, increases in stumpage fees for roundwood would increase the savings available to the pulpmill by replacing roundwood with chips. The full value of stumpage fees when considering the residual pricing approach should be the end-product price in the first competitive market encountered; in this case, pulp minus all costs to reach that market including a reasonable profit for the firm. In arriving at a residual amount to be allocated to stumpage and profit increasing the stumpage will arbitrarily reduce that portion of residual called profit. Under these circumstances, the pulpmill will want to subsidize their costs of inputs to production by buying more cheaper residue wood chips from the sawmills.

Care would have to be taken in introducing such a policy because it may result in too much roundwood being left in the woods. Therefore, there would have to be a readjustment in the A.A.C. ${ }^{7}$ An evaluation of the social benefits and costs in light of the significant impact on pulpmills compared with that on the sawmill industry would probably result in one concluding that a policy that promotes residue utilization could not be implemented without considering the greater importance of the pulpmill industry.

Alternatively, a simple constraint on total roundwood input, below the capacity of the pulpmill insures that the pulpmill uses a certain quantity of chips. A combination of charging full stumpage value for roundwood and imposing an upper limit on roundwood input would be most effective in ensuring optimum residue utilization. At the same time, there need not be interference with the discriminatory pricing system for chips. Again to actually introduce such a policy would involve investigating the social benefits and costs.

The second policy issue arises in planning a changing industrial structure. For example, say that at some time there was to be another major pulpmill in Alberta; there would be considerable expectation of the buoyant effects of increased "competition" on chip prices and hence a hope that residue utilization would rise dramatically. It is important to distinguish between the effect of competition and reduced transporation costs from a change in industrial structure.

Figure 3 illustrates the possible effects of introducing another pulpmill to a region. It shows the case in which the new pulpmill (pulpmill 2) partly overlaps an existing pulpmill's "chipshed" (pulpmill 1). The lines labed with 1's and 2's indicate the prices that would be offered by the pulpmills respectively. In the area of overlap between points $\mathrm{N}$ and $\mathrm{R}$ some producer's surplus will be provided to the sawmills. The existing pulpmill (pulpmill 1) would be able to beat the best price at the sawmill which the new pulpmill (pulpmill 2) would be able to offer in area NO, based on the MR2 of (pulpmill 2), and the new pulpmill (pulpmill 2) would be able to beat the best price that the existing pulpmill could offer in area OR, based on the MR1 of (pulpmill 1).

This would increase the producer's surplus to existing sawmills but would not increase the amount of residue

${ }^{7}$ Annual allowable cut. 


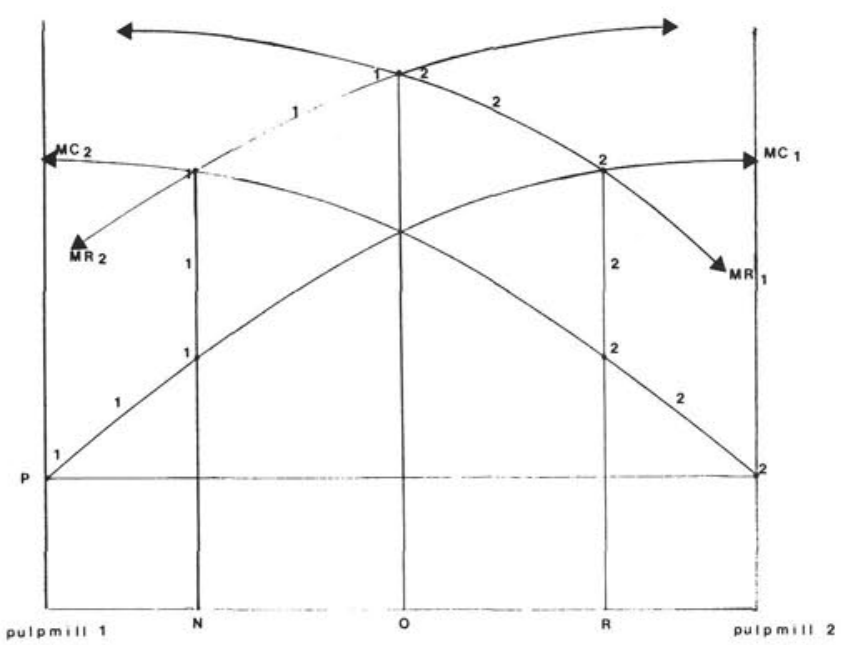

Figure 3. Impact of chipshed overlap

utilization if (pulpmill 2) was entirely within the chipshed of the existing pulpmill (pulpmill 1). However, if (pulpmill 2) was located beyond the chipshed of the original pulpmill (pulpmill 1) new sawmills could be offered a price similar to that of firms in the other chipshed. Obviously, the pattern for new pulpmill location that will maximize wood residue utilization is to locate outside the existing mill's chipshed.

Usually the location of any pulpmill facility would be predicated on other critiera besides residue utilization including roundwood availability and existing infrastructures. A policy that promotes economic efficiency for chip producers may overlook the possible decrease in pulpmill efficiency. If a locational policy would result in a decrease in economic efficiency for the pulpmill, alternatives uses for sawmill residues would have to be considered. These studies did not evaluate the net social benefits and costs involved in locating a pulpmill inside or outside a particular chipshed except to show the net benefits of increased residue utilizations. Such a policy would have to be evaluated further to determine the overall impact.

The prospect of increased competition from monopsony to oligopsony by closer locations of new mills is of little social consequence. Pulpmills having to pay higher prices for chips would not increase their level of utilization of chips in the short run and might actually decrease the level of utilization in the long run. Increased competitition would result in more producer's surplus going to the sawmills, thereby increasing the cost of chips relative to roundwood for the pulpmill.

\section{Summary}

Monopsonistic chip pricing with price discrimination by location of supplier is a pricing policy that tends to ensure a degree of chip utilization closer to the socially optimum level, than a monopsonistic pricing policy without discrimination. Rather than regulate the chip purchasing policies of pulpmills, it is more effective to ensure that alternative roundwood supplies are priced up to their full residual value taking end use price and costs into account.

The current situation of pulpmills being allocated sufficient sources of wood in their Forest Management Agreement so that they do not need chips from sawmills is a situation that will likely continue. The impact of present policies on the development of the sawmill and pulpmill industry creates a conflict between pulpwood and residues for pulp. A policy that promotes higher residue utilization may only conflict with the higher priority of promoting larger industry development, which has traditionally been provided enough wood so firms do not need sawmill residues.

\section{References}

Geldhart, G and M. Carroll. 1980. The marketing of wood chips in Alberta. Dept. of Rural Economy, Bulletin 21.

MacDonald, A.P. 1983. The utilization of wood chips in Alberta. M.Sc. Thesis. University of Alberta.

\title{
Woodlot Service (1978) Ltd.
}

"All Matters Pertaining to Forestry"

\author{
GORDON B. YOUNG, B.Sc.F., M.F. \\ Registered Professional Forester
}

320 Maple Street

Fredericton, N.B.

Bus.: 506-458-9366

E3A 3B4

Home: 506-472-7721 